\title{
Knowledge of Teachers in Regards to Childhood Malnutrition and Reported Nutrition Information Resources
}

\author{
Mary Damilola Adu ${ }^{1,}$, , Ikeoluwapo Oyeneye Ajayi ${ }^{1}$, Kayode Titus Adu ${ }^{2}$ \\ ${ }^{1}$ Department of Epidemiology and Medical Statistics, Faculty of Public Health, University of Ibadan, Ibadan, Nigeria \\ ${ }^{2}$ School of Land and Food, Tasmania Institute of Agriculture, University of Tasmania, Hobart, Australia
}

Email address:

adumdammy@gmail.com (M. D. Adu), ikeajayi2003@yahoo.com (I. O. Ajayi), aduktus@gmail.com (K. T. Adu)

To cite this article:

Mary Damilola Adu, Ikeoluwapo Oyeneye Ajayi, Kayode Titus Adu. Knowledge of Teachers in Regards to Childhood Malnutrition and Reported Nutrition Information Resources. European Journal of Preventive Medicine. Vol. 4, No. 1, 2016, pp. 13-19. doi: 10.11648/j.ejpm.20160401.13

\begin{abstract}
It is important to examine teacher's knowledge on malnutrition since they are at the vanguard of the implementation of the school based malnutrition prevention programs and therefore has the vital role to influence nutrition information and behaviour in children. It is only teachers with accurate and substantial information that can orientate the children rightly. This study set out to assess the knowledge levels of teachers on malnutrition in childhood and to explore resources used for information on nutrition. This cross sectional study was conducted among 387 male and female teachers who agreed to participate from 26 public and 13 private primary schools in 3 semi-urban communities in Ido Local Government, Ibadan, Nigeria. A structured and pretested questionnaire was self- administered and collected immediately. Data collected was analysed using SPSS version 16 statistical software. The Mean knowledge score was 49.9; 214(55.3\%), $145(37.5 \%), 28(7.2 \%)$ teachers had good, fair and poor levels of knowledge respectively. Handbook (80.4\%), television $(70.5 \%)$ and radio $(62.5 \%)$ were the major resources reported for use on nutrition information. Based on the findings of this study, percentage of teacher's with adequate knowledge on childhood malnutrition is not sufficient. In-service training focusing on the causes, effects, symptoms and prevention of malnutrition in childhood would be invaluable; teachers should also be provided with relevant text books that can enhance their knowledge on nutrition issues.
\end{abstract}

Keywords: Risk Factors, Effects and Prevention of Childhood Malnutrition, Nutrition Resources

\section{Introduction}

Childhood malnutrition, in different magnitude is found in all nations of the world and its effect on performance, health and survival had been the subject of research for several decades. Childhood malnutrition had been shown to have short and long term implication on health and was associated with $54 \%$ of death in developing countries [1-2]. Malnutrition literally means 'bad nutrition' and technically includes both under- and over-nutrition. According to The World Food programme (WFP), malnutrition is a state in which the physical function of an individual is impaired to the point where he or she can no longer maintain adequate bodily performance such as growth, physical work, resisting and recovering from disease [3].

To prevent the consequences of malnutrition, studies have proposed that preventive effort should start in early childhood through nutrition and physical education in schools [4]. This has led to the implementation of School Health Programs which includes comprehensive, well implemented malnutrition prevention interventions in form of; dissemination of nutrition and physical information and good dietary practices to promote children's health and fitness [5-7]. Primary schools are particularly suitable because at this stage, nutrition lessons are simple, interesting, colorful and easily learned through demonstration, illustrations, and practical approaches which are natural to nutrition education; thus creating awareness, understanding on the benefits of healthy eating and impacting skills for physical activity therefore inducing positive behaviour change towards healthy food and physical exercise,. This will invariably improve the health status of children and eventually prevent malnutrition [8-9].

Teachers have a broader and long accepted responsibility for supporting the health of their students; since many children and adolescents are expected to be 
enrolled in school, where they spend more time than in any environment away from home [10-11]. Teachers have the potential to play a significant role in an effort to improve, develop or positively influence students' dietary behaviour; by disseminating nutrition information through formal interactions and by serving as role models through informal interactions with students [12]. School teachers could be useful source of nutrition information for students but they would have to possess adequate and precise knowledge of nutrition issues. Research has shown that teachers quality, whether measured by content, knowledge, experience, training or credentials is strongly related to the type of information that will be disseminated to students [13]. Therefore school teacher's knowledge of malnutrition is an essential factor in optimising their function as educators on how to prevent malnutrition in school children. Understanding of teacher knowledge is useful to make educational innovations more successful [14]. In the curriculum for primary school education in Nigeria, nutrition issues is not taught as a standalone subject but is integrated into health education and other subjects. A study revealed that adequate knowledge of school health programme is low among Nigerian primary school teachers [15].

Teachers have the role of providing vital information to promote knowledge and understanding on the causes, effects and preventive strategies for malnutrition thus leading to positive behavioral change towards nutrition issues and physical activities among pupils. Teacher's knowledge about malnutrition will influence how they will be able to perform this role. However, literatures on the evaluation of teachers who are at the vanguard of the implementation of these school based malnutrition prevention interventions are limited. Therefore there is a risk that huge investment in malnutrition prevention intervention in primary schools might not yield the desired result in Nigeria if the knowledge of teachers on the components of the targeted disease is not acknowledged, as only teachers with accurate and substantial knowledge can orientate the children rightly. Thus, the purpose of this study was to provide data on; the malnutrition knowledge and sources of nutrition information of primary school teachers. The first objective was to; assess teacher's level of knowledge on malnutrition. The second objective was to access the resources used for nutrition information. In achieving these objectives; the following research questions were raised.

1. What is the level of knowledge of teachers on malnutrition?

2. What are the resources teachers access to acquire information on nutrition issues?

These information are important for understanding messages that may be given by teachers to pupils and for planning intervention that may be needed by teachers so as to enhance effective implementation of school-based malnutrition prevention intervention programmes.

\section{Methods}

\subsection{Study Area}

This cross sectional study was conducted in February and March, 2010 among teachers in the Ido Local Government Area (LGA) of Ibadan, Oyo state, Nigeria. The LGA is semiurban in nature and mostly inhabited by farmers and petty traders.

\subsection{Sample Size and Sampling Technique}

The sample size for this study was calculated using this equation

$$
\mathrm{N}=\frac{\mathrm{Z}^{2}[\mathrm{P}(1-\mathrm{P})]}{\mathrm{d}^{2}}
$$

Where ' $z$ ' is the critical value, and in a two tailed test, it is equal to 1.96 , due to paucity of data on teacher's malnutrition knowledge, $50 \%$ was adopted as the estimate of teachers with proper knowledge of malnutrition; which is $p$ and $d$ is the estimated accuracy set at $5 \%$. Therefore the minimum sample size was calculated as: $\mathrm{n}=\left[1.96^{2}(0.5)(0.5)\right] \div(0.05)^{2}$

This gave a sample size of 384 . In anticipation of a response rate of $90 \%$, sample size was increased to 426 .

A multistage sampling technique was used to select these samples.

\subsection{Study Instrument}

The structured questionnaire was designed based on review of relevant literature and basic childhood malnutrition knowledge. It was self- administered by classroom teachers of the selected schools. To ensure the content validity of the instrument, the questionnaire was referred to 4 experts in the fields of child health and health education to ascertain its relevance, appropriateness and clarity. The questionnaire was pretested among 20 teachers in another school not included in the study. A test-retest method of reliability was applied to the questionnaire and was administered to them on two occasions one week apart. For all the domains of the questionnaire; Spearman's correlation coefficient varied from $0.71-0.88$. Following the pre-testing, the necessary adjustments were made to facilitate understanding of the instrument by the participants.

The first section of the questionnaire collected background information of the respondents including; age, sex, highest educational qualification, years of teaching experience, year of most recent qualification.

The second section tested participants' knowledge on malnutrition. "Knowledge" in this study was accessed using five domains of "the knowledge of the risk factors, symptoms, effects, current trends and prevention of malnutrition in children". An assumption was made in this study that knowledge of these five critically important aspects would contribute towards teacher's ability to properly function in their responsibility as nutrition educators. To test for knowledge of risk factors, we put forth some inaccurate propositions (e.g consumption of 
protein rich foods causes kwashiorkor in children) and a set of accurate ones (inadequate dietary intake, frequent infections and diseases; as causes of malnutrition). We employ the same format to inquire about respondents' knowledge on the effects and prevention of malnutrition. Some of the inaccurate propositions that were included in this regards are; "malnutrition in children can cause improved performance in academic work", "consumption of foods rich in vitamin A can prevent scurvy in children" while "children's brain can be affected by malnutrition resulting into low intellectual power", "schools commitment to promoting healthy food intake in her environment prevent malnutrition", constituted the accurate ones. We adopted a "Yes", "No" or "I don't know" options to questions assessing knowledge on the current trends and symptoms of malnutrition.

The third section of the questionnaire inquired about the resources respondents' have used in time past to acquire information on nutrition. Respondents were allowed to choose more than one option.

\subsection{Data Analysis and Management}

SPSS statistical software (version XVI; SPSS Inc. Chicago, IL) was used for all analyses. Data was summarized using descriptive statistics such as means, range, standard deviations and percentages. Student t-tests and Anova were used to test for associations between categorical and continuous variables respectively. A ' $p$ value' less than 0.05 was considered to be statistically significant. The number of questions in each of the knowledge domains were; causes (6), effect (5) current trends (4), symptoms (14) and prevention (10). All questions were weighed equally during scoring and each correct answer was assigned a score of 2 points while a wrong or not sure response was scored 0 . This makes maximum obtainable points of 79 . Overall scores was computed as a continuous numerical variable and then converted into 3 equal parts as categorical variables to represent levels of knowledge. This includes 'poor', 'fair' or 'good' levels of knowledge. There was also a mean knowledge score of the respondents by their background characteristics.

\subsection{Ethics Statement}

Ethical approval for this study was obtained from the Ethical Review Board of the Oyo state Ministry of Health. A letter of approval was granted by the Education board. Signed informed consent was also obtained from each participant upon proper understanding of the research process.

\section{Results}

\subsection{Background of Respondents}

The response rate was $90 \%(387 / 429)$. Their age ranged from 20 to 59 years with a mean age of $37.5 \pm 9.1$ years. Most of the respondents were female 257(66.4\%). Years of experience in teaching profession ranged from 1 to 34 years with a mean of $10.4 \pm 8.2$ years. Most of the respondents $(n=228,58.9 \%)$, had the National Certificate in Education as their highest educational qualification.

\subsection{Knowledge of Childhood Malnutrition}

\subsubsection{Knowledge on the Risk Factors for Malnutrition (Table 1)}

Majority, 302(78\%) rightly know that "inadequate food hygiene and childcare can result into undernutrition" and 306 (79.1\%) noted high consumption of dietary fat, carbohydrate and sweetened drinks as part of the causes of overweight and obesity. Three hundred and one $(77.8 \%)$ knows that a child can become malnourished if he/she lacks knowledge about food nutrients and right food choices. However, not up to half of the respondents $(47.3 \%)$ have the knowledge that deficiency in the consumption of protein rich foods result into kwashiorkor in children.

Table 1. Respondents Knowledge on the risk factors of malnutrition $(N=$ 387).

\begin{tabular}{lllc}
\hline Knowledge Items & Correct & \multicolumn{2}{c}{ Correct answers } \\
\hline & response & N & $\%$ \\
\hline $\begin{array}{l}\text { Inadequate dietary intake and diseases are } \\
\text { immediate causes of undernutrition }\end{array}$ & true & 291 & 75.2 \\
$\begin{array}{l}\text { Frequent infection and diseases in children } \\
\text { can result into undernutrition }\end{array}$ & true & 247 & 63.8 \\
$\begin{array}{l}\text { Inadequate food hygiene and childcare can } \\
\text { result into undernutrition }\end{array}$ & true & 302 & 78.0 \\
$\begin{array}{l}\text { A child can become malnourished if he/she } \\
\text { lacks knowledge about food nutrients and } \\
\text { food choices }\end{array}$ & true & 301 & 77.8 \\
$\begin{array}{l}\text { High consumption of protein rich food } \\
\text { causes Kwashiorkor in children }\end{array}$ & false & 183 & 47.3 \\
$\begin{array}{l}\text { High consumption of dietary fat, } \\
\text { carbohydrate and sweetened drinks in } \\
\text { children can result into Overweight and } \\
\text { obesity }\end{array}$ & true & 306 & 79.1 \\
\hline
\end{tabular}

\subsubsection{Knowledge on the Effects of Malnutrition (Table 2)}

Additionally, $338(87.3 \%)$ of them knew that undernutrition can result into low intellectual ability in children and $311(80.4 \%)$ correctly noted that adequate nutritional status of children can lead to better attendance and high enrolment in school. However, a larger percentage $(54.8 \%)$ of them lacks the knowledge that undernutrition can result into frequent infections such as malaria and diarrhea.

Table 2. Knowledge on the effects of malnutrition.

\begin{tabular}{llcc}
\hline Knowledge Items & Correct & \multicolumn{2}{c}{ Correct answers } \\
\hline & response & N & \% \\
\hline $\begin{array}{l}\text { Children's brain can be affected by } \\
\text { undernutrition resulting into low Intellect }\end{array}$ & true & 338 & 87.3 \\
$\begin{array}{l}\text { Undernutrition cannot result into frequent } \\
\text { infection (such as malaria, diarrhoea) }\end{array}$ & false & 175 & 45.2 \\
$\begin{array}{l}\text { Adequate nutritional status in children } \\
\text { can be responsible for better attendance } \\
\text { and high enrolments in school }\end{array}$ & true & 311 & 80.4 \\
$\begin{array}{l}\text { Undernutrition in children can cause } \\
\text { improved performance in academic work } \\
\begin{array}{l}\text { Obesity can result into poor attention and } \\
\text { poor memory in school children }\end{array}\end{array}$ & true & 218 & 56.3 \\
\hline
\end{tabular}




\subsubsection{Knowledge on Current Trends of Malnutrition in Children}

A larger portion, 375(92.3\%) of the respondents rightly indicated that malnutrition is a problem among Nigerian primary school children and that undernutrition is a form of malnutrition $359(92.8 \%)$. On the other hand, only 151 (39.0\%) was able to recognise overnutrition as a form of malnutrition but $275(71.1 \%)$ knew that it is possible for school children to be overweight or obese.

\subsubsection{Knowledge on the Symptoms of Undernutrition and Overnutrition (Table 3)}

Also, 362(93.5\%) and 286(73.9\%) of the respondents were able to identify poor growth and restlessness respectively as signs in undernourished children but not up to half of them $43(11.1 \%)$ were able to recognise scaling and cracking of lips and mouth as an obvious sign of undernutrition in children. Also, only a few percentage $104(26.9 \%)$ and $97(25.1 \%)$ knew that prominent facial and collar bone respectively were not features of overnourished children.

Table 3. Knowledge of symptoms of undernutrition and overnutrition $(N=$ 387).

\begin{tabular}{llll}
\hline Variables & Correct & \multicolumn{2}{l}{ Correct answers } \\
\hline & response & N & $\%$ \\
\hline Symptoms of Undernutrition & & & \\
Fatigue & Yes & 311 & 80.4 \\
Poor eye sight & Yes & 335 & 86.6 \\
Poor growth (shortness for age) & Yes & 362 & 93.5 \\
Dry sparse hair that falls out easily & Yes & 293 & 75.7 \\
Restlessness & Yes & 286 & 73.9 \\
Dry and scaly skin & Yes & 292 & 75.5 \\
Decaying teeth & Yes & 216 & 55.8 \\
Scaling and cracking of lips and mouth & Yes & 43 & 11.1 \\
Symptoms of overnutrition & & & \\
Prominent facial bone & No & 104 & 26.9 \\
Obesity & Yes & 323 & 83.5 \\
Bone and joint problems & Yes & 222 & 57.4 \\
Perpetual protruded abdomen & Yes & 274 & 70.3 \\
Prominent collar bone & No & 97 & 25.1 \\
Depression & Yes & 222 & 57.4 \\
\hline & & & \\
\hline
\end{tabular}

\subsubsection{Knowledge on Prevention of Malnutrition (Table 4)}

Similar number of respondents 176(45.5\%) rightly noted that 'a balanced diet is not one that contains high proportion of fat' and that 'whole grains (e.g. rice and maize) represents the best calorie needed by the body'. Also, 298 (77\%) knew that teachers are key elements in the development of healthy eating habit among pupils. However only a few percentages $(8.8 \%)$ rightly answered that consumption of foods rich in vitamin A does not prevent scurvy.
Table 4. Respondents knowledge of prevention of malnutrition ( $N=387)$.

\begin{tabular}{|c|c|c|c|}
\hline \multirow[t]{2}{*}{ Knowledge Items } & \multirow{2}{*}{$\begin{array}{l}\text { Correct } \\
\text { response }\end{array}$} & \multicolumn{2}{|c|}{ Correct answers } \\
\hline & & $\mathbf{N}$ & $\%$ \\
\hline $\begin{array}{l}\text { A healthy and adequate diet is } \\
\text { important in the prevention of diseases } \\
\text { such as pellagra, ricket, obesity, } \\
\text { kwashiorkor }\end{array}$ & true & 341 & 88.1 \\
\hline $\begin{array}{l}\text { School children's participation in } \\
\text { physical activities is a way of } \\
\text { promoting a healthy lifestyle }\end{array}$ & true & 348 & 89.9 \\
\hline $\begin{array}{l}\text { Teaching nutrition and physical } \\
\text { education at the primary school level } \\
\text { can prevent malnutrition in children }\end{array}$ & true & 232 & 59.9 \\
\hline $\begin{array}{l}\text { Consumption of food rich in vitamin A } \\
\text { can Prevent scurvy (bleeding gum) in } \\
\text { children }\end{array}$ & false & 34 & 8.8 \\
\hline $\begin{array}{l}\text { Commitment of the school to } \\
\text { promoting healthy food intake in her } \\
\text { environment can prevent malnutrition }\end{array}$ & true & 312 & 80.6 \\
\hline $\begin{array}{l}\text { Nutritional habit at maturity depends } \\
\text { on nutritional habit in childhood }\end{array}$ & true & 272 & 96.1 \\
\hline $\begin{array}{l}\text { Teachers are key element in the } \\
\text { development of healthy eating habit } \\
\text { among pupils }\end{array}$ & true & 298 & 77.0 \\
\hline $\begin{array}{l}\text { A balanced diet is one that contains } \\
\text { high proportion of fat. }\end{array}$ & false & 177 & 45.7 \\
\hline $\begin{array}{l}\text { Whole grains(e.g. rice, maize) } \\
\text { represent the best calorie needed by the } \\
\text { body }\end{array}$ & true & 176 & 45.5 \\
\hline $\begin{array}{l}\text { Regular physical activity is an } \\
\text { important Factor in the prevention of } \\
\text { childhood obesity }\end{array}$ & true & 327 & 84.5 \\
\hline
\end{tabular}

\subsubsection{Overall Knowledge}

Respondents mean knowledge score was $49.9 \pm 9.5$ points with a range of $18-68$ points. This was grouped into 3 equal parts and graded 'poor 'if score is equal or between 18 and 34 , 'fair' if equal or between 35 and 51, and 'good' if equals or between 52-68 points. Approximately, an average $214(55.3 \%)$ of them had a good knowledge level (i. e scored 52 points or above), $145(37.5 \%)$ had a fair knowledge while 28(7.24\%) scored between $18-34$ points and were therefore graded poor in their level of knowledge.

A comparison of mean knowledge score of respondents by their background characteristics are presented on Table 5 . This comparison showed no significant difference.

Table 5. Comparison of respondents mean knowledge score $(X)$ by their background information.

\begin{tabular}{l|lll|l}
\hline $\begin{array}{l}\text { Background } \\
\text { characteristics }\end{array}$ & $\begin{array}{l}\text { Mean } \\
(\mathbf{x})\end{array}$ & SD & $\begin{array}{l}\text { Frequency } \\
\text { (n) }\end{array}$ & $\begin{array}{l}\text { Test } \\
\text { statistics } \\
\text { and p value }\end{array}$ \\
\hline $\begin{array}{l}\text { Educational qualification } \\
\text { Grade II }\end{array}$ & 48.7 & 10.23 & 17 & \\
$\begin{array}{l}\text { National Certificate } \\
\begin{array}{l}\text { Examination } \\
\text { Bachelor/Higher }\end{array}\end{array}$ & 49.2 & 9.42 & 228 & $\mathrm{f}=1.54 ;$ \\
$\begin{array}{l}\text { National Diploma } \\
\text { Masters }\end{array}$ & 50.6 & 10.18 & 73 & $\mathrm{p}=0.190$ \\
$\begin{array}{l}\text { Others (such as Ordinary } \\
\text { Sex }\end{array}$ & 53.6 & 5.17 & 5 & \\
$\begin{array}{l}\text { Malional Diploma) } \\
\text { Female }\end{array}$ & 49.8 & 9.11 & 64 & \\
\hline
\end{tabular}




\begin{tabular}{lllll}
\hline $\begin{array}{l}\text { Background } \\
\text { characteristics }\end{array}$ & $\begin{array}{l}\text { Mean } \\
(\mathbf{x})\end{array}$ & SD & $\begin{array}{l}\text { Frequency } \\
(\mathbf{n})\end{array}$ & $\begin{array}{l}\text { Test } \\
\text { statistics } \\
\text { and p value }\end{array}$ \\
\hline $\begin{array}{l}\text { Type of school } \\
\text { Public }\end{array}$ & 49.93 & 9.44 & 282 & $\mathrm{t}=-0.041 ;$ \\
$\begin{array}{l}\text { Private } \\
\text { Teaching experience(years) }\end{array}$ & & & $\mathrm{p}=0.967$ \\
$1-9$ & 51.10 & 9.00 & 207 & \\
$10-19$ & 48.50 & 9.56 & 116 & $\mathrm{f}=2.327$ \\
$20-29$ & 48.68 & 9.80 & 59 & $\mathrm{p}=0.740$ \\
$30-39$ & 50.80 & 16.41 & 5 & \\
\hline
\end{tabular}

\subsection{Resources for Nutrition Information}

The most mentioned resources for nutrition information was handbook $311(80.4 \%)$, followed by the media whose order of use includes; television $273(70.5 \%)$, radio 242 $(62.5 \%)$ and newspaper $228(58.9 \%)$. Approximately half, $190(49.1 \%)$ of the respondent reported getting information on nutrition issues from their trainings at tertiary education. The web based resources, $100(25.8 \%)$ was the least mentioned.

\section{Discussion}

\subsection{Malnutrition Knowledge}

Approximately, an average of the respondents in this study had a good knowledge of malnutrition and related issues. However, the fact that the percentage of teachers with good knowledge level were only an average proved a lack of fundamental information as there were some questions that were rightly answered by only a few percentage of the participants. For instance not up to half of the respondents knew that high consumption of protein rich foods is not a risk factor for kwashiorkor in children. This is consistent with a study in Accra Ghana, where kwashiorkor remains endemic and was attributed to lack of knowledge about the nutrition needs of young children [16]. This lack of knowledge on the importance of adequate intake of protein in children may inhibit participants' ability to encourage food providers for school children (e.g parents, food vendors) to adequately provide foods rich in protein content for the consumption of children.

Likewise, majority never knew that undernutrition can result into frequent infections (such as malaria, diarrhea). This finding is comparable to the report of Food and Agricultural Organisation, 2005 study on dietary knowledge, attitude and practices which reveals that undernutrition was not generally recognised as a risk factor for diseases, except in acute cases, and the idea of a good diet preventing illness was not widespread [17] Other basic questions where a larger number of respondents lack knowledge includes; consumption of foods rich in vitamin A does not prevent scurvy in children, overnutrition as a form of malnutrition. Moreover, only a few numbers of participants were able to recognise scaling and cracking of lips and mouths as an obvious symptom of malnutrition in children and that overnourished children are not likely to present with prominent facial and collar bone. There were no published studies that assessed the knowledge levels on these questions.

The knowledge level of teachers about malnutrition is very important because teachers with sufficient information can help develop a healthy community; as early habits for a healthy community with healthy individuals are formed firstly in schools through pupils' interaction with their teachers and it continues on [18]. Studies have shown that teachers use their knowledge base of subject matter for decision making. When teachers themselves lack the understanding of ideas, they are unable to provide experiences and activities that guide students' progress towards the understanding of such ideas [19], therefore sound teachers' subject content knowledge positively influence decision on strategies of assessment, implementation of curriculum and curriculum development [20].

Meanwhile, the highest educational qualification for majority of the respondents $(58.9 \%)$ was the National Certificate of Education (NCE) - the minimum qualification for primary school teachers in Nigeria [21]. However, a few $(4.5 \%)$ of the respondents indicated that their highest educational qualification was the teachers Grade II certificate. The current finding is in line with the findings of a study that stated that teachers with Grade II certificate are still found among the qualifications of teachers in Nigerian Primary Schools in many states in the country [22]. The current study found that knowledge score among respondent increases with higher educational qualification where those was grade II qualification had the lowest overall score. This might affect their ability to effectively orientate the pupils on nutrition issues as teachers' qualifications significantly determine the quality of teaching and education provided to the young children [23]. Therefore stakeholders in education should always endeavor to organise refresher courses and sponsor teachers for further training to equip them with improved knowledge and training skills.

\subsection{Nutrition Resources}

Handbook, the media and trainings at the higher institution were the foremost mentioned nutrition resources. These sources especially the handbook is more likely to discuss current recommendations and it is a readily available and reliable guidance on nutrition issues [24]. However, the web based resources which are now a very accessible source of nutrition and health information [25] was only indicated by a few of the respondents. This shows that teachers need to be educated on the usefulness of exploring the internet to support their self-training on nutrition information which will help them educate their students on nutrition issues.

This study was carried out in only one of the 774 LGAs in Nigeria hence it is not generalizable. However it has provided useful information that can guide policy and highlighted the need to carry out similar studies in the other geopolitical zones especially the northern part of Nigeria where malnutrition in children is predominant. 


\section{Conclusion}

The percentage of teachers found with good knowledge on childhood malnutrition is not optimal. This could affect the quality of information teachers give to pupils in their role as nutrition educators and implementers of school based malnutrition prevention programs. There should be provision for regular and continued education training to increase the percentage of teachers with adequate knowledge on malnutrition especially in the areas where there is gap (such as in the current trends, symptoms, effects and prevention of malnutrition). Also, it is of utmost importance that relevant and modern textbooks on nutrition be provided for teachers use especially for the preparation of subject curriculum. These training and resources stand to increase their knowledge on issues relating to childhood malnutrition. These measures are required in order to fully utilize schools as a setting for prevention of malnutrition among children.

\section{Acknowledgement}

Special thanks go to the head teachers in all the schools where data were collected and teachers who responded to the questionnaire.

\section{Authors' Contributions}

MD and IO conceived the study; MD, IO and KT participated in research design. MD and KT participated in data collection. MD, IO and KT participated in data analysis and interpretation. MD wrote the first draft of the manuscript. IO and KT gave critical contribution in the review of the manuscript. All authors read and approved the final manuscript.

\section{References}

[1] Monika B, Mercedes O. Malnutrition: quantifying the health impact at national and local levels. Environmental Burden of Disease Series. 2005. Geneva, Switzerland: World Health Organisation.

[2] Pelletier DL, Frongillo EA Jr., Schroeder DG, Habicht J.P. A methodology for estimating contribution of malnutrition to child mortality in developing countries. J Nutr. 1994; 124 Suppl: S2106-22.

[3] World Food Programme. Food and Nutrition Handbook 2000. Rome. World Food Programme.

[4] Food and Agricultural Organisation. Nutrition education in primary schools 2005; Vol. 1: The Reader. Rome: FAO. Available at http://www.fao.org/3/a-a033e.pdf.

[5] Story M, Nanney MS, Schwartz MB. Schools and obesity prevention: creating school environments and policies to promote healthy eating and physical activity. Milbank $Q 2009$ Mar; 87(1): 71 - 100. Doi: 10.111/i. 1468-00092009.00548 x.
[6] Bundy D, Shaeffer S, Jukes M, et al. "School based health and nutrition programs". "Diseases control priorities in developing countries ( $2^{\text {nd }}$ edition), $1901-1108$. New York: Oxford University Press DOI: 10.1596/978-0-821-36179$5 / \mathrm{Chpt}-58$.

[7] Kandiah J and Jones C. Nutrition knowledge and food choices of elementary school children. Early Child Development and Care 2002; 172(3): $269-273$.

[8] Friel S, Kelleher C, Campbell P, Nolan G. Evaluation of the nutrition education at primary school (NEAPS) programme. $J$ Public Health Nutrition, 1999; 4: 549-555.

[9] Belansky ES, Romaniello C, Morin C, et al. Adapting and implementing long term nutrition and physical activity curriculum to a rural, low income, biethnic community. J Nutr Educ Behav 2006; 38: 106 - 113.

[10] Bandura A. Observational learning. In Social foundations of thought and action: A social cognitive theory. Englewood Cliffs, NJ: Prentice Hall. 1986 (169 - 195).

[11] Bronfenbrenner M. The ecology of human development. Experiment by nature and design. Harvard University Press; 1979. P. 21.

[12] Kubik MY, Lytle LA, Hannan PJ, Story M, Perry CL. Food related beliefs, eating behaviour and classroom food practices of middle teachers. Journal of School Health, 2002; 72: 339 345 .

[13] Darling - Hammond, L. Teacher quality and student achievement: A review of state policy evidence. Washington DC: centre for the study of teaching policy, University of Washington. (Research Report; 1999: R-99-1).

[14] Verloop N, Van Driel J, Meijer P. Teacher's knowledge and the knowledge of teaching. Int Jour Educ research 2001; 35(5): 442-461.

[15] Ofovwe GE and Ofili AN. Knowledge, Attitude and Practice of School Health Programme among head teachers of primary schools in Egor Local Government of Edo State, Nigeria. Ann Afr Med 2007; 6:99-103. Available from: http://www. Annalsafrmed.org/text.asp?2007/6/3/99/55726.Doi:10.4103/1 596.55726 .

[16] McGadney-Douglass BF, Douglass RL, Garrison ER, Antwi P and B Owusu. Social and behavioural characteristics of longterm survivors of kwashiorkor in Ghana. Annual Meeting, African Studies Association, Philadelphia, Pennysylvania, USA; 1999.

[17] Food and Agricultural Organisation. Knowledge, attitude, perceptions and practices: a study on nutrition (children under five years and pregnant and lactating women) in the project "Improving household food security and nutrition in Luapula Valley, Zambia”, Project 2002; GCP/ZAM/052/BEL.

[18] Sezenler A. and Caglar M. What is the role of education technologies in increasing information levels on nutrition among primary school teachers? TOJET 2007; 6(4): 91-95.

[19] Harlen, W. and James, M. Assessment and learning: differences and relationships between formative and summative assessment, Assessment in Education 1997; 4: 365-79. 
[20] Carr, M., McGee, C., Jones, A., McKinley, E., Bell, B., Barr, H. and Simppson, T. Strategic research initiatives: the effects of curricula and assessment on pedagogical approaches and on educational outcomes. Ministry of Education, Wellington, New Zealand. 2000.

[21] Sofolahan JO. National Policy on Education Review Issues, in UNESCO (Ed). The state of Education in Nigeria, UNESCO Abuja; 1998.

[22] Butu BM, Madu SB, Hassan MN. Dilemma of teacher education in teacher's preparation. RJMSTNG December 2012; 31(1):2.
[23] Abdulkadir K. Investigating demographic characteristics and teaching perceptions of Turkish preschool teachers. Jour Early Child Development and Care. Obesity Report 2008; 1.

[24] Ellie Whitney and Sharon Rady Rolfes. Understanding Nutrition: $11^{\text {th }}$ ed: Wadsworth Publishers; 2007.

[25] Underbakke G, McBride PE,Spencer E. Web- based resources for medical nutrition education. Am J Clin Nutr April 2006; 83(suppl): 9615-9555. 